\title{
Edistyksellinen tutkimus Suomessa
}

Tutkijaliitto valmistautuu marraskuun lopulla pidettävään 2. liittokokoukseensa.

Liittokokoukselle on annettu haastava yleisteema: edistyksellinen tutkimus Suomessa. Ei ole suinkaan sattuma, että liiton hallitus viime toukokuussa määritteli liittokokousvalmistelujen ja itse kokouksen johtavan teeman juuri näin. Tämä teema ilmentää monipuolisesti Tutkijaliiton perustavanlaatuisia tehtäviä.

E n s i n $\mathbf{n}$ ä $\mathbf{k}$ i $\mathbf{n}$ teema nousee esiin tiedepoliittisesta tilanteesta, jonka olennaisena piirteenä ovat olleet toistuvat, usein raivokkaat hyökkäykset kaikkea edistyksellistä tutkimusta vastaan; hyökkäykset, joita on johtanut ennen muuta KTTS, jotka ovat kääntyneet tieteen kehityksen perusperiaatteita vastaan ja joiden vaikutukset ulottuvat kaikille tieteenaloille. Tällä hetkellä ei ole tärkeämpää ajankohtaista tehtävää kuin koota yhteen eri alojen tutkijoita puolustamaan ja kehittämään niitä edistyksellisiä tutkimustraditioita, jotka taantumus haluaa juuria pois tämän maan tieteellisestä maaperästä. Tosiasia on, että esim. Meteli- ja Tandem tutkimusten tulokset on virallisissa arviointiseminaareissa arvostettu hyvin korkealle. Kuitenkin juuri ne ovat olleet voimakkaimman parjauskampanjan kohteena.

T o i s e k s i liittokokouksen teema vastaa Tutkijaliiton perustehtäviä: tehtäväämme tukea kansallisen, edistyksellisen tieteen kehitystä. Tämä voi tapahtua vain nojautumalla oman maamme kaikkiin edistyksellisiin traditioihin, pitämällä tutkimuksen kehittämisen mittana työtätekevien etuja ja demokratiaa, suuntautumalla näiden periaatteiden pohjalta kansainväliseen keskusteluun ja yhteistyöhön.

$\mathrm{K}$ o $1 \mathrm{~m} \mathrm{a} \mathrm{n} \mathrm{n} \mathrm{e} \mathrm{k} \mathrm{s} \mathrm{i} \mathrm{liittokokousteeman} \mathrm{takana} \mathrm{on} \mathrm{perusteltu} \mathrm{vakaumus}$ tieteellisen edistyksen välttämättömyydestä ja mahdollisuudesta. Tieteellistä tutkimustyötä kehittämällä on mahdollista saada oikeata tietoa luonnon ja yhteiskunnan lainmukaisuuksista ja ottaa tämä inhimillisen toiminnan perustaksi. Tietenkään tämä ei tapahdu automaattisesti, eikä se riipu pelkästään tieteestä. Siksi tarvitaan liittoa yhteiskunnallista edistystä ajavien voimien kanssa, tieteen ja edistyksen liittoa. Tiede ja edistys, yhteiskunnallinen edistys ja edistyksellinen tutkimus. Tämä on Tutkijaliiton tärkein tehtävä ja tärkein tunnus.

Tutkijaliiton 2. liittokokoukselle valmistellaan laajan käsittelyn kautta järjestöpoliittista asiakirjaa. Sen tarkoituksena on koota yhteen liiton työn tähänastiset kokemukset, tehdä niistä johtopäätökset ja laskea perusta järjestön tulevalle kehittämiselle. Liitto on ollut olemassa kaksi ja puoli vuotta. Ratkaiseva on se kokemus, mikä tänä aikana on saatu omasta työstä ja ystävien tuesta. Tältä pohjalta on kyettävä tekemään johtopäätökset ja otettava seuraavat tietoiset askeleet liiton kehittämiselle.

Erityisen huomion kohteena asiakirjaluonnoksissa on toiminnan kehittäminen perustasolla - laitoksissa, korkeakouluissa, kaikkialla, missä tutkijat työskentelevät. Perusteellisesti paneudutaan myös akateemisen yhteisön u l$\mathrm{k}$ o p u o l e 11 a työskentelevien tutkijoiden toiminnan järjestämiseen ja tu- 
kemiseen. Olosuhteet siellä ovat hyvin erilaiset kuin korkeakouluyhteisössä, ja monessa suhteessa vaikeammat: tieteellisen yhteisön tuki puuttuu, tutkijat työskentelevät varsin eristettyinä, työnantajan tai esimiesportaan kontrolli on tiukkaa ja täysin ulkotieteellistä jne. Kuitenkin esim. julkisen hallinnon piirissä asiantuntija-, suunnittelu- ja tutkimustehtävissä työskentelevien tieteellisten työntekijöiden panos vallankumouksessa ja demokraattisessa liikkeessä voi olla huomattavan suuri.

Tutkijaliiton perusyksiköiden työn kehittymisestä viime kädessä riippuu se, mihin tuloksiin koko liitto yltää. Perustasolla, tutkijoiden keskuudessa, on kyettävä luomaan yksiköitä, jotka yhtäältä kykenevät seuraamaan oman tieteenalansa ja laitoksensa tiedepoliittista kehitystä, näyttämään suuntaa edistykselliselle tutkimukselle, reagoimaan kaikkiin taantumuksen toimenpiteisiin, ja jotka toisaalta kehittyvät aitoina tieteellisinä kollektiiveina tukien ja kannustaen jokaisen jäsenen oman tutkimustyön etenemistä. Miten tämä kaikki toteutetaan - se on ratkaistava järjestöpoliittisen asiakirjan järjestökäsittelyn yhteydessä.

Perustason organisaation ja toiminnan korostuminen seuraa myös tiede- ja korkeakoulupoliittisen tilanteen muuttumisesta. Juuri nyt on noustava puolustamaan laitoksissa, tieteellisen työn perusyksiköissä $t \mathrm{u} \mathrm{t} \mathrm{k} \mathrm{i} \mathrm{m} \mathrm{u} \mathrm{k} \mathrm{s} \mathrm{e} n$ a inee 11 isia ja henkisiä ede11ytyksiä. Kapitalismin kriisin oloissa heikennetään Suomessa näitä kumpiakin. Samalla on olemassa vaara siitä, että toteutetaan laajempia muutoksia tieteellisten laitosten rakenteessa ja toimintaperiaatteissa lähtien hyvin kapean pragmaattisesta tieteenkäsityksestä. Tutkimuksen tuloksellisuuden nimissä pyritään saattamaan tieteelliset laitokset entistä läheisempään kosketukseen elinkeinoelämän - so. monopolien - etujen kanssa. Varoittavia esimerkkejä tästä on paljon. Voidaan ottaa esiin vaikkapa EVA:n suunnitelmat Tampereen yliopiston toimittajakoulutuksen saattamisesta kustantajien valvontaan, Helsingin yliopiston tiedotusopin opetuksen muuttamiseen tähtäävä professuurilahjoitus, tai Teknillisessä korkeakoulussa ajankohtainen pyrkimys muuttaa yhdyskuntasuunnittelun jatkokoulutuskeskus rakennusyritysten vientiä palvelevaksi organisaatioksi. Jatkuvasti tulee myös esiin se, että tieteelliseen yhteisöön ja tutkimustyöhön kohdistuvaa byrokraattista määräilyä pyritään lisäämään. Tämähän on noussut hyvin keskeiseksi kysymykseksi tutkinnonuudistusta koskevassa keskustelussa. On selvästi käynyt ilmi, miten haitallista on sekä opetuksen että tutkimuksen kannalta ulkotieteellisin kriteerein toimivan hallituksen hallintokoneiston kasvu opetusministeriössä ja korkeakouluissa.

Tätä kirjoitettaessa on valtion tulo- ja menoarvioesitys vuodeksi 1979 juuri julkaistu. Se ilmentää tutkimuksen taloudellisten edellytysten heikkenemistä: Kun koko budjetin loppusumman nimelliskasvu on $16 \%$, on vastaava luku korkeakoululaitoksen osalta $5 \%$ ja budjetointiluokan "yleinen tutkimus" osalta $6 \%$. Korkeakoulujen virkojen ja toimien lisäys on 16; tämä on lopullinen osoitus korkeakoulujen kehittämislain tavoitteiden täydellisestä vesittämisestä, 
joka samalla luonnehtii tutkimustyön edellytysten jatkuvaa heikkenemistä.'Tämä vaikuttaa väistämättä myös opetuksen tasoon, korkeakoululaitoksen mahdollisuuksiin suoriutua perustehtävistään. Tilanne on vakava. Vähääkään liioittelematta voidaan puhua tiede- ja kulttuuriskandaalista.

Kapean pragmaattiseen hyötyyn sidotun tiedenäkemyksen laajeneminen jättää vuosi vuodelta selvemmät jäljet valtion tiederahoitukseen. Budjettiesityksessä luvataan teollisuutta tukevaan tutkimukseen $20 \%$ lisäys verrattuna viime vuoteen. Teknisen tutkimuksen rahoittaminen kauppa- ja teollisuusministeriön elinten kautta on sekä tieteen että demokratian vaatimusten vastaista: se kytkee tutkimukset yritysten etuihin ja voittopyrkimyksiin, mikä estää sekä tieteellisen arvioinnin ja vuorovaikutuksen että tutkimustavoitteiden demokraattisen valvonnan. Eräs kuvaava budjetin yksityiskohta on, että Suomen Akatemian tutkimusmäärärahoihin ja tutkimussopimuksiin esitetty miljoonan markan lisäys on sidottu tukemaan "taloudellista elvytystä ja talouden rakennemuutosta". Taikasana "elvytys" pyhittää kaiken, varsinkin monopolien edut.

Ainekset tämän kehityksen vastustamiselle ovat kypsymässä. Tutkimuksen itsenäisyyden ja riippumattomuuden sekä tieteellisen keskustelun periaatteiden kunnioittamisen vaatimukset ovat saaneet keskustelussa lisää tukea ja kantavuutta. On selvää, että puolustaessaan t i e t e e 11 i s i ä periaatteita $\mathrm{h}$ a 1 1 i n n o 11 i s i a puuttumisia vastaan tutkijat puolustavat paitsi omia välittömiä työskentelymahdollisuuksiaan myös tieteellisen edistyksen edellytyksiä yleensä.

Samalla tutkijoiden keskuudessa etsitään ratkaisuja konkreettisiin ongelmiin kuten rahoituksen supistumiseen, nuoren tutkijakunnan työttömyyteen, oikeusturvan loukkauksiin jne. Eräs asia näiden ongelmien kohdalla on selvä. Ne eivät ratkea itsestään, niiden ratkaiseminen vaatii tutkijoiden omaa toimintaa, tiedepoliittisen taistelun kehittämistä, tukeutumista edistyksellisiin voimiin koko yhteiskunnassa.

Tutkijaliiton liittokokous käsittelee myös tiedepolitiikan kysymyksiä. Kokoukselle valmistellaan tiedepoliittinen aloite, jonka kokous osoittaa keskustelun herättämiseksi ja yhteistoiminnan kehittämiseksi kaikille tutkijoille, koko tieteelliselle yhteisölle. Aloitteessa esitetään ratkaisua maamme tutkimuksen kehitysedellytysten uhkaavalle kaventumiselle; se osoittaa, että $t$ i e t e e $n$ $\mathrm{p}$ u o l u s t a m i n e $\mathrm{n}$ on vallitsevan tilanteen asettama tehtävä. Aloitteen valmistelu on avointa - Tutkijaliitto ei ole salaseura, vaan tutkijoiden järjestö, joka tekee mitä sen jäsenet ja ystävät haluavat sen tekevän ja mitä edistyksellisen tieteen puolustamiseksi on välttämätöntä tehdä. Aloitteen luonnosteluvaiheessa sen tekemiseen kootaan liiton koko tiedepoliittinen asiantuntemus. Pyydämme jo siinä yhteydessä myös ystäviemme mielipiteitä ja kommentteja, ja tulemme liittokokouksen jälkeen tiedepoliittisen aloitteen pohjalta esittämään laajaa yhteistoimintaa konkreettisen toiminnan käynnistämiseksi. 
Näiden arvioiden ja suuntaviivojen pohjalta Tutkijaliitto valmistautuu 2. liittokokoukseensa. Se pidetään Helsingissä 18.-19. marraskuuta. Toivotamme liittomme jäsenet, ystävät ja kannattajat tervetulleiksi seuraamaan liittokokoustamme ja osallistumaan sen työskentelyyn.

\section{Tässä numerossa}

Kapitalismin imperialistinen vaihe nosti erääksi keskeiseksi marxilaisen yhteiskunta-analyysin kysymykseksi ns. sivistyneistön tai intellektuellien aseman kapitalismissa. Länsi-Euroopassa tämä kysymys on koettu ongelmalliseksi erityisesti vuoden 1968 liikehdintöjen jälkeen. Bertolt Brechtiä ongelma sivistyneistön yhteiskunnallisesta asemasta oli askarruttanut jo 1930-luvulla. Esa Sironen erittelee artikkelissaan "Brecht ja intellektuellit" Brechtin näkemyksiä ns. sivistyneistön roolista erityisesti Saksan Weimarin tasavallassa ja ylipäänsä kapitalismissa.

Ensi keväänä suhteellisuusteorian kehittäjän Albert Einsteinin syntymästä on kulunut 100 vuotta. Käsittelemme tässä numerossamme suhteellisuusteoriaa. Jussi Timonen esittelee Einsteinin suhteellisuusteorian syntyä ja Osmi Vilhu erittelee artikkelissaan avaruuden ja ajan käsitteitä. Näiden käsitteiden muovautumiseen saattaa koko fysiikan tuleva kehitys olla sidoksissa.

Keijo Rahkonen käsittelee artikkelissaan Marxin "Lisäarvoteorioiden" paikkaa suhteessa Marxin "Pääoman" kolmeen kirjaan. Voidaanko "Lisäarvoteorioita" pitää "Pääoman" neljäntenä kirjana? Mikä merkitys "teorian historian" tutkimuksilla on Marxin tuotannossa? Nämä kysymykset koskettelevat koko marxilaisen tutkimuksen metodologiaa.

Lehtemme on jo aikaisemmissa numeroissaan käsitellyt aggression tutkimuksen ongelmia. (Tiede ja edistys 4/1977 ja 1/1978). Tässä numerossa jatkamme aiheen tarkastelua. Julkaisemme Yrjö Engeströmin artikkelin koululaisten väkivaltaisesta käyttäytymisestä, missä Engeström lähestyy aihetta kasvatustieteelliseltä kannalta.

Lähinumeroissamme on tarkoitus käsitellä materialistisen psykologian kehittämistä ja porvarillisen psykologian kritiikkiä. Tässä numerossa aloitamme tämän teeman käsittelyn julkaisemalla Klaus Holzkampin, joka on psykologian professori Länsi-Berliinissä, artikkelin 'Marxin 'Pääoma' ja psykologian tieteellistyminen", missä Holzkamp kertoo omasta vuoristopolustaan ja tämän polun mutkista "Pääomaan" tutustumisen ja sen omaksumisen kautta porvarillisen psykologian kritiikkiin ja edelleen positiiviseen "'kriittiseen psykologiaan". 